\title{
Financial Architecture and Corporate Performance: Evidence from Russia
}

\author{
Kokoreva M. ${ }^{7}$, Stepanova A. ${ }^{8}$
}

The study was implemented under the grant of Economics Department of the National Research University Higher School of Economics in 2011

In this paper we study the performance effects of capital structure, ownership structure choices and corporate governance mechanisms of Russian companies. To address the lack of research in corporate performance modeling in emerging markets we contribute to the literature by introducing cluster analysis of financial architecture and market performance of Russian companies. Our idea is to find out the efficient and inefficient types of financial architecture in emerging markets. On the sample of 50+ largest Russian nonfinancial companies within the period of 2005-2010 years we demonstrate the existence of three sustainable types of financial architecture in Russia. Using cluster analysis we form the cluster of companies in pre-crisis period and then demonstrate the relationship between the financial architecture type and the level of corporate market performance.

\section{$J E L: G 32, G 34$}

Keywords: financial architecture, capital structure, ownership structure, emerging markets, corporate performance

\section{Introduction}

In this paper we apply conception of corporate financial architecture to take into account different non-financial characteristics of a company together with non-traditional methodology for corporate performance maximization.

First, we need to explain why we use corporate financial architecture as a basic conception for performance modeling. Traditional approach to the study of relationship between firm's nonfinancial characteristics and corporate performance considers the performance modeling based on one or several indicators of capital structure, ownership structure or corporate governance. There are two key disadvantages in such type of research. The first one is that such studies while modeling performance drop a deal of important information, since the authors usually study one of the dimensions (e.g. state ownership, size of the board or something else). The second one is that we do not account for interrelations between different characteristics. Let's assume we study the emerging market with low level of institutional investors and less than optimal debt level. We find that to maximize the performance we need to raise the financial leverage and to attract more institutional investors. But what if institutional investors dislike high leverage (that is natural)? So, actually we could either attract institutional investors, or raise the financial leverage, that proves that while modeling the performance we should take into account the interrelations between different financial architecture components.

This conception introduced by S.Myers in 1999 considers several corporate dimensions such as capital structure (or financial leverage), ownership structure, corporate governance mechanisms and legal form of the company as an integrated system. According to Myers, we should consider

\footnotetext{
${ }^{7}$ Junior Research Fellow, Lecturer, Corporate Finance Center, National Research University Higher School of Economics

${ }^{8}$ Junior Research Fellow, Assistant Professor, Corporate Finance Center, National Research University Higher School of Economics
} 
different dimensions all together not to develop so-called stylized models, i.e. models that could explain a phenomenon but have low forecasting power.

Second, besides traditional regression analysis we use cluster analysis while modeling the performance. It helps us not only to consider the corporate financial architecture as a whole system but also to understand if there are sustainable types of architecture in Russia. Sustainable types of architecture could be used by the board of directors and top management for building or rebuilding up a company to make it as efficient as possible at the moment. In this paper we conduct the analysis of market efficiency measured as Tobin's Q coefficient, so that if we succeed in finding this 'most efficient architecture' we could also speak about the maximization of company's market value.

We conduct our analysis on the sample of 50+ largest Russian nonfinancial companies that publish their reports according to IFRS or US GAAP within 2005-2010 years. We start with the descriptive analysis of ownership structure and capital structure. On the second stage we determine the clusters of companies based on ownership, Board and capital structure criteria. We proceed with empirical testing of the relationship between elements of financial architecture and market performance measured with Tobin's Q in dynamics to determine the most sustainable clusters. We also pay special attention to the analysis of clusters dynamics before and after the credit crunch.

The rest of the paper is organized as follows. Section 2 contains brief literature review. In Section 3 the methodology of the study is presented. Section 4 describes major empirical results. Section 5 concludes.

\section{Literature review}

The existing literature typically concentrates on the influence of a separate company's characteristic (like ownership concentration or state participation) over corporate performance. As we already mentioned above the key idea of the authors is to take into account different characteristics of the company integrated into financial architecture system. In this section we present short review of literature devoted to interrelations of different components of financial architecture with market performance of the companies.

We start with the performance effect of capital structure. We are not going to speak much about two common known theories of performance effect of capital structure. The trade-off theory and pecking order hypothesis were tested for many times using different samples [Frank et al. 2005; Shyam-Sunder, Myers, 1999; Myers 1984; Halov et al. 2005], so that we could reject the hypothesis of irrelevance of capital structure in imperfect market with significant income taxes, costs of financial distress, etc. Information asymmetry and agency problems raise the role of capital structure through agency costs and signalling power [Baker 2002; DeMarzo et al. 2004; Atkeson 2005]. Recent research also considers behavioural aspects as a catalyst of performance effect of capital structure [Elliott et al. 2008; Frank, Goyal 2009; Barros, Silveira 2004]. Actually regardless of the theory preferred, capital structure influences the corporate performance through cost of capital and agency costs' minimization effects of the optimal capital structure.

In emerging markets the majority of recent papers on capital structure are devoted to the capital structure determinants identification [Seifert, 2008; Ni, 2008; Ivanov, 2010]. The second popular research direction is capital structure optimization based on the trade-off theory [Frank et al., 2005; Shyam-Sunder, Myers, 1999; Shakhina, Kokoreva, 2010], empirical testing of pecking order hypothesis [Myers, 1984; Halov et al, 2005], signalling and agency models [Baker, 2002; DeMarzo et al., 2004; Atkeson, 2005; Yang Ni, 2009]. There is also a new popular research direction devoted to the interrelations between different financial decisions: capital structure choice and payout policy [Atieh \& Hussain, 2008; Noronha et al., 1996], capital budgeting [Hennessy, Whited, 2005; Cai, J., Zhang, Z., 2011] including papers based on hypothesis of endogeneity of capital structure [Brailsford et al., 2002; Margaritis, Psillaki, 2010].

The problem of ownership structure optimization has been studied since 1980s in several aspects such as insiders' ownership, state ownership, ownership concentration and others. The 
major mechanism of performance effect of ownership structure is the agency conflicts between managers and shareholders [Holderness et al., 1999; Kesner, 1988; Kole, 1995; Morck et al., 1988], major and minor shareholders [Burkart et al., 1997; Dyck, Zingales, 2004; Grossman, Hart, 1988; Nenova, 2000], state and private investors. Thus we have 3 different ownership structure indicators we should consider.

Research on insiders' management often shows different results even within national samples. In earlier research we can find the results demonstrating linear, non-monotone and insignificant relationship. The most up-to-day view on the relationship between insiders' ownership and corporate performance implies the existence of non-monotone relationship with the breakpoint depending on geopolitical factors [Holderness et al., 1999; Kesner, 1988; Kole, 1995; Lloyd et al., 1986]. Non-monotone relationship could be explained with 2 hypotheses. According to 'interest alignment' hypothesis, the firm value should grow with the increase in insiders' ownership because of the increase in managers' motivation to maximize company's performance. According to 'management entrenchment' hypothesis, managers prefer to lower the risk level instead of maximize the value when they have very large holdings in the company since their personal risks are too concentrated in one company [Morck et al., 1988].

Minority discrimination and high monitoring costs as well as liquidity issues made us formulate the classic hypothesis on performance effect of ownership concentration [Dyck, Zingales, 2004; Grossman, Hart, 1988; Nenova, 2000; etc.]. The results of this hypothesis testing in Russia are not robust [Кузнецов, Муравьев, 2000; Радыгин, Энтов, 2001; Ivashkovskaya, Stepanova, 2011].

One of the most popular research directions in this area is state ownership and its efficiency analysis. On the one hand, state as an economic agent that pursues its own goals that may conflict with value maximization. On the other hand, the company gets access to government guarantees, additional financing and other benefits [Alchian, 1961, 1965; Boycko et al., 1996; Laffont, Tirole, 1993; Megginson, Netter, 2001; Stiglitz, 1988; Vickers, Yarrow, 1988]. In Russia the level of state ownership in the largest companies is strongly negative correlated to ownership concentration that leads us to the proposition of existence of two typical financial architectures for Russian companies: one is of state-controlled companies and another one is controlled by the group of up to 3 private owners [Stepanova, 2009].

In late 1990 s and 2000 s the problem of endogeneity of capital structure and ownership structure has been actively discussed [Brown, Earle, 2000; Himmelberg et al., 1999; Claessens, Djankov, 1999; Kumar, 2004] together with the problem of potential reversed relationship. Instrumental variables and systems of simultaneous equations became the key instruments for regression analysis taking into account the endogenous capital and ownership structures. Results are quite different but there is evidence proving, for example, capital structure dependence of company size [Brailsford et al., 2002].

All the above-mentioned phenomena made us consider the alternative instruments for analysis of performance effect of company's financial architecture. One of the potential alternative methods is cluster analysis that allows us to find out sustainable types of corporate financial architecture and then to analyse performance effect between these groups. The cluster analysis has only recently appeared in capital structure research [Li, Li, 2008; $\mathrm{Su}, 2010]$ but there are still no papers devoted to integrated analysis of financial architecture and firm performance.

Choosing the integrated conception of financial architecture for performance modeling we take the responsibility for taking into account all the important elements of company's financial design. So, we also need to consider its corporate governance mechanisms that are usually reflected in the structure of board of directors. First, there is a very common view that independent directors in the board raise its performance by adding the expertise and proposing independent opinion on the company's strategic decisions. Second, according to opinion of many top-managers and researchers, size of the board may have a significant negative influence over corporate performance due to longer and more expensive decision-making process [Jensen, 1993].

The thorough analysis of previous studies some of which are mentioned above allows us to 
formulate the following hypotheses:

1. There exist several types of corporate financial architecture in Russia that differ significantly;

2. Type of financial architecture influences company's market performance significantly;

3. Types of financial architecture are indifferent to the sector (industry specific factors).

This set of hypotheses leads us to the model we develop in the next paragraph.

\section{Methodology and data}

\section{Sample description}

Our analysis is based on the sample of Russian largest actively traded non-financial companies that prepare their financial reports according to IFRS or US GAAP accounting standards. The sample period is 2005-2010 years (2004 data was used to calculate sales growth rates). The financial data was initially gathered from Bloomberg database and the gaps were filled up with the data from the audited financial reports allocated on the official sites of the companies. All the data is presented in the US dollars.

Ownership structure and corporate governance information was gathered from the annual reports of the companies. As this information is not as transparent, the final sample consisting of 52 companies is represented by the slightly unbalanced panel. Market base information (capitalization, beta coefficients) is also unavailable in some cases due to late IPO processes or reorganization of companies accompanied by delisting. The descriptive statistics of our sample is presented in Appendix 1.

\section{Methodology}

Our research was conducted in two stages. The hierarchical cluster analysis (average linkage method) was used at the first stage. We divided the sample into several subsamples: precrisis period data for 2005-2007 years, crisis period: 2008, 2009 and post crisis 2010 year. The division was made to examine carefully the dynamics of cluster characteristics and firms movements from year to year.

The following criteria of corporate financial architecture were used for data clustering:

- Capital structure variables: Total debt ratio calculated as total interest bearing debt to the sum of total interest bearing debt and book value of equity

- Ownership variables: ownership concentration calculated as the share of three largest shareholders; foreign ownership measured as the share of equity held by foreign investors from developed capital markets

- Board of Directors variables: size proxied by the total number of the Board members; independency rate measured as the number of independent members of the Board of Directors to the total number of the Board members ratio.

The clusters obtained were examined from different perspectives. Firstly we analyzed the measures of firm performance in each cluster: market performance measured as Tobin's Q coefficient (market value of equity to book value of equity ratio), return on equity (ROE), return on total assets (ROA), growth rates of sales and capital expenditures. Secondly we monitored whether the same firms were clustered similarly from year to year. Thirdly we checked whether the firms from one industry were gathered in one cluster or not.

The second stage of our research implied regression analysis of the market performance determinants.

We run the following linear regressions using panel data with fixed effects method (for 2008, 2009 and 2010 cross section analysis was applied): 
(1) $Q_{i t}=\alpha_{0}+\alpha_{1}$ TDR ${ }_{i t}+\alpha_{2} O C 3_{i t}+\alpha_{3}$ Ind $_{i t}+\alpha_{4}$ Size $_{i t}+\alpha_{5}$ foreign $_{i t}+\alpha_{6}$ gsales $+\alpha_{7}$ prof $_{i t}+\varepsilon_{i t}$

where Q- Tobin's Q coefficient, TDR - total debt ratio; OC3 - ownership concentration of three major shareholders; Ind - rate of Board independency; Size - size of a company measured as natural logarithm of total assets; prof - profitability measured as EBIT to total assets; gsales growth rates of sales (three variables of sales growth rates were used: precrisis growth rates (years 2004-2007), overall growth rates (2005-2010 years), moving average growth rates with two years interval).

Within the other variables that were included in regressions specifications are the following: Tang - tangibility of assets calculated as fixed assets to total assets ratio; Size1 - size of a company measured as natural logarithm of sales; beta - measure of market risk of the firm (beta coefficient); ROE - return on equity; Doil - dummy variable equals to 1 if the firm operates in oil and gas industry, 0 otherwise; Dcr - dummy variable equals to 1 if the firm operates in customer and retail industry, 0 otherwise; gcapex - capital expenditures to total assets ratio as a measure of capital expenditures growth rates and the expected future growth.

The correlation matrix of the variables is presented in Appendix 2.

\section{Empirical results}

The cluster analysis on subsamples for different time periods revealed the existence of three clusters. The statistics of the clusters are presented in Appendix 3. The clusters are persistent in stable, crisis and post crisis periods. Moreover the companies show almost no movements from cluster to cluster across the time. The analysis of industries structure of clusters revealed no industry effects in clusters formation.

The clusters revealed could be characterized by the following features.

Cluster 1: Russian companies in this cluster experience the most sustainable growth. The cluster could be described by the declining management ownership share and the growing ownership of foreign investors from the developed markets. The level of independent directors in the Board is about 30\%. This cluster shows the Tobin's Q coefficient around 2 before and after the crisis, and 1.5 during the crisis accompanied by the stable growth in capital expenditures and the positive sales growth rates before the crisis and across the whole sample period. The level of debt is the lowest across the clusters (approximately $28 \%$ in stable periods).

Cluster 2: The cluster is characterized by the lowest foreign investors' ownership and the largest management ownership. The level of debt in the cluster is as high as about $30 \%$ before the crisis and $40 \%$ after the crisis. The low rates of return on total capital together with the growth rate decreasing during the crisis are accompanied with a weak negative growth rate for the entire study period.

Cluster 3: Companies in this cluster, characterized by approximately equal management and foreign investors ownership, have the highest level of ownership concentration, the highest level of debt, leading to the highest ROE indicators with an average profitability ratios. The growth rates of capital expenditures in these companies are the highest before the crisis, but move to the lowest levels after the crisis. The sales growth rates undergo a similar scenario that leads to a negative cumulative growth rate during the research period. Tobin's Q coefficient before the crisis takes on ungrounded high values for the period of stable economic situation (about 2.9), experiences strong fluctuations in the crisis period and after it, due to both fluctuations in the market value of equity, and with the reduction of book value of equity during the crisis.

Thus we believe that the combined analysis of market performance, growth rates and profitability measures lead us to the conclusion that the clusters are sorted from the most efficient to the least efficient ones. The third cluster, although demonstrating extremely high Tobin's Q ratios, reveals the short-term character of positive growth and therefore is represented by the unsustainable companies.

The results of the regression analysis revealed the determinants of market performance. 
Across every time period profitability, debt ratios and company's size are the significant determinants. On the contrary, ownership concentration and industries show no effects on the market performance of a firm. Nevertheless these results should be considered as pilot and require thorough endogeneity analysis in further research.

\section{Conclusion and discussion}

The analysis conducted allowed us to develop an original classification of financial architecture types in Russian capital market. We determined the most effective type of financial architecture that results in the most sustainable market performance after the global financial turmoil. Thorough analysis of dynamic cluster results allows deriving the recommendations concerning the optimization of corporate financial architecture to achieve sustainable growth of nonfinancial companies in emerging markets.

Our cluster analysis resulted in finding out three sustainable types of financial architecture of large Russian nonfinancial companies. In our particular opinion, the first one is the most efficient one since it allows support high level of market performance in the periods of high volatility. Independent board of directors (over 30\% of independency), modest level of insiders' ownership, conservative capital structure and a significant foreign participation drive sustainable growth and pretty attractive market performance.

Locally owned companies with high management ownership and medium debt level demonstrated high performance before the crisis but low sustainability level when Tobin's q goes below 1 and still negative (or zero) level of sales growth in 2010.

Finally, companies with the highest ownership concentration level and owners involved into governance process demonstrate high market performance even after crisis while the growth rates are strongly negative.

So, we achieved our initial goal to analyze not the separate influence of some company's characteristics over performance but the system of company's financial architecture that could be efficient or inefficient as a whole in Russian business environment.

Further research will be concentrated on the cross-country analysis including Eastern European countries where investment climate and business environment is comparable to Russian one. After that we are going to use this methodology to compare the process of financial architecture building-up and its performance effect in developed and emerging markets.

\section{References}

1. Ивашковская И. В., Солнцева М. С.. Детерминанты стратегических решений о финансировании крупных компаний на развивающихся рынках капитала: пример России, Бразилии и Китая. Российский журнал менеджмента Т.7, №1, 2009 г., 25-42

2. Кузнецов П., Муравьев А. Механизмы участия государства в управлении акционерными обществами государственной и смешанной форм собственности в России. Вестник Санкт-Петербургского университета. Серия 8, 2002, Выпуск 1(8), 5480

3. Степанова А.Н. Влияние финансовой архитектуры компании на ее стратегическую эффективность. «Финансы и кредит», №44, ноябрь 2009, стр. 38-45

4. Atieh, A. and Hussain, S. Disaggregating 'accounting earnings' to better explain UK dividends, // Applied Financial Economics Letters, 4: 6, 2008, 399 — 401

5. Brailsford, Oliver, Pua. On The Relation of Ownership Structure and Capital Structure// Accouting and Finance, 2002, 42: $1-26$

6. Brown, Earle Coles, J., McWilliams, V. \& Sen, N. An Examination of the Relationship of Governance Mechanisms to Performance// Journal of Management, 2001, 27(1), 23-55

7. Caves, D., Christensen, LR and Swanson, JA (1980), 'Productivity in US railroads', Bell Journal of Economics, 11, 166-81 
8. Claessens, Djankov. Ownership Concentration and Corporate Performance in the Czech Republic// CEPR Discussion Paper,1999, 2145

9. Consequences. Journal of Political Economy, 1985, 93, 1155-1177.

10. Demsetz, H., and K. Lehn. The structure of corporate ownership: Causes and

11. Fama E. F., \& Jensen, M. C. Separation of ownership and control// Journal of Law and Economics, 1983, 26, 301-325

12. Frank M.Z., Goyal V.K. Trade-Off and Pecking Order Theories of Debt// Handbook of Empirical Corporate Finance, Volume 2 Edited by B. Espen Eckbo, 2008, p.135-202

13. Himmelberg, Glenn, Darius. Understanding the Determinants of Managerial Ownership and the Link between Ownership and Performance// Journal of Financial Economics, 1999, 53: $353-384$

14. Ivanov I. Capital Structure determinants of Russian public companies// Журнал «Корпоративные финансы», 1(13) 2010, с.5-38

15. Jensen, J.C., 1993, "The Modern Industrial Revolution, Exit, and the Failure of Internal Control Systems". Journal of Finance, 48: 1-80.

16. Kokoreva M.S., Shakhina N.A. Empirical Testing of Dynamic Capital Structure Choice: Case of Russian Companies. E-Journal "Corporate Finance", 4(16), 2010, 31-40

17. Kumar. Does Ownership Structure Influence Firm Value? Evidence from India// SSRN Working Paper, 2004

18. Maxim Boycko, Andrei Shleifer and Robert W. Vishny. A Theory of Privatisation The Economic Journal.Vol. 106, No. 435 (Mar., 1996), pp. 309-319

19. Myers, S. The Capital Structure Puzzle// Journal of Finance, 1984, 39, pp. 575-592

20. Myers, S.C. Financial architecture// European Financial Management, 5, 1999, pp. 133-141

21. Ni J., Yu M. Testing the Pecking-Order Theory. Evidence from Chinese Lister Companies // The Chinese Economy, 2008, № 1, vol. 41, pp.97-113

22. Seifert B., Gonenc H. Pecking Order Behavior in Emerging Markets // Working paper, 2008

23. Shyam-Sunder L., S.C.Myers. Testing Static Trade-Off against Pecking Order Models of Capital Structure// Journal of Financial Economics, 1999, 51, pp.219-244

24. Vickers, John \& Yarrow, George, 1988. "Regulation of privatised firms in Britain," European Economic Review, Elsevier, vol. 32(2-3), pages 465-472 
Appendix 1. Descriptive statistics of the sample

\begin{tabular}{|c|c|c|c|c|c|}
\hline Variable & Obs & Mean & Std. Dev. & Min & Max \\
\hline \multicolumn{6}{|c|}{ Total sample } \\
\hline gsales_t & 310 & .1591079 & .1441983 & -.1116582 & .7249448 \\
\hline gsales_p & 288 & .3588154 & .22542 & .0018324 & 1.246115 \\
\hline gsales_m & 260 & .2336335 & .4931267 & -.4219331 & 6.498903 \\
\hline tdr & 302 & .4426682 & .6428516 & 0 & 9.598102 \\
\hline mtdr & 292 & .3522878 & .2926083 & 0 & 1 \\
\hline Tang & 302 & .5153687 & .2177321 & .0315869 & .9312729 \\
\hline oc3 & 312 & .6861437 & .2258968 & 0 & 1 \\
\hline foreign & 312 & .0740497 & .1770652 & 0 & .9349 \\
\hline Ind & 292 & .3175731 & .1933824 & 0 & .9090909 \\
\hline tq & 276 & 2.03276 & 1.903588 & 0 & 9.798117 \\
\hline prof & 300 & .1144074 & .104921 & -.3114493 & .5113177 \\
\hline roe & 302 & .073007 & .566886 & -6.348531 & 2.970773 \\
\hline size & 302 & 7.773236 & 1.486666 & 4.568672 & 12.61975 \\
\hline size1 & 302 & 7.493159 & 1.381071 & 4.569355 & 11.85959 \\
\hline gcapex & 291 & .0960175 & .0744407 & 0 & .5849887 \\
\hline beta & 275 & .7749393 & .4109028 & -.519 & апр.67 \\
\hline Variable & Obs & Mean & Std. Dev. & Min & Max \\
\hline \multicolumn{6}{|c|}{ Precrisis } \\
\hline gsales_t & 154 & .1595552 & .1447957 & -.1116582 & .7249448 \\
\hline gsales_p & 144 & .3588154 & .2258138 & .0018324 & 1.246115 \\
\hline gsales_m & 108 & .4469622 & .6589383 & -.0647061 & 6.498903 \\
\hline tdr & 147 & .3694705 & .245317 & .0035947 & 1.514869 \\
\hline mtdr & 139 & .2998411 & .3053921 & 0 & 1 \\
\hline tangibility & 147 & .5284539 & .2103197 & .0315869 & .9312729 \\
\hline oc3 & 156 & .6795143 & .2622523 & 0 & 1 \\
\hline foreign & 156 & .0417512 & .1361587 & 0 & .9154 \\
\hline independ & 138 & .2887862 & .1662362 & 0 & .6666667 \\
\hline tq & 131 & 2.330953 & 2.008598 & 0 & 9.798117 \\
\hline prof & 144 & .133568 & .1009373 & -.2208928 & .5113177 \\
\hline roe & 147 & .1378538 & .2897606 & -2.364034 & .8115895 \\
\hline size & 147 & 7.567685 & 1.490126 & 4.568672 & 12.52697 \\
\hline size1 & 147 & 7.314332 & 1.403638 & 4.687278 & 11.44528 \\
\hline gcapex & 141 & .1017264 & .0711311 & 0 & .4252474 \\
\hline beta & 127 & .7805402 & .4937807 & -.519 & апр.67 \\
\hline Variable & Obs & Mean & Std. Dev. & Min & Max \\
\hline \multicolumn{6}{|c|}{2008 data } \\
\hline gsales_t & 52 & .1586663 & .1450098 & -.1116582 & .7249448 \\
\hline gsales_p & 48 & .3588154 & .2274097 & .0018324 & 1.246115 \\
\hline gsales_m & 49 & .294469 & .1801769 & -.2038138 & .6767547 \\
\hline tdr & 52 & .4591912 & .4088233 & 0 & 2.950448 \\
\hline mtdr & 52 & .506633 & .2757853 & 0 & .9376565 \\
\hline tangibility & 52 & .5046182 & .2193629 & .0656756 & .8903631 \\
\hline
\end{tabular}




\begin{tabular}{|c|c|c|c|c|c|}
\hline oc3 & 52 & .7014703 & .1598442 & .199 & 1 \\
\hline foreign & 52 & .075281 & .1724589 & 0 & .9063 \\
\hline independ & 52 & .362437 & .2031499 & 0 & .7777778 \\
\hline tq & 51 & 1.104765 & 1.399739 & .0751215 & 8.720411 \\
\hline prof & 52 & .1088336 & .1250124 & -.3114493 & .3666905 \\
\hline roe & 52 & -.0288157 & 1.034419 & -6.348531 & 2.970773 \\
\hline size & 52 & 7.93905 & 1.43709 & 5.059864 & 12.40413 \\
\hline size1 & 52 & 7.771628 & 1.328892 & 5.33918 & 11.85959 \\
\hline gcapex & 51 & .1238626 & .0955339 & 0 & .5849887 \\
\hline beta & 50 & .803322 & .4968253 & -.1605 & фев.06 \\
\hline Variable & Obs & Mean & Std. Dev. & Min & Max \\
\hline \multicolumn{6}{|c|}{2009 year } \\
\hline gsales_t & 52 & .1586663 & .1450098 & -.1116582 & .7249448 \\
\hline gsales_p & 48 & .3588154 & .2274097 & .0018324 & 1.246115 \\
\hline gsales_m & 52 & -.012728 & .1856525 & -.4219331 & .5510858 \\
\hline tdr & 52 & .60166 & 1.310357 & 0 & 9.598102 \\
\hline mtdr & 51 & .3803002 & .2656967 & 0 & .9337933 \\
\hline tangibility & 52 & .5120858 & .2191127 & .0816396 & .8968258 \\
\hline oc3 & 52 & .702741 & .175961 & .199 & 1 \\
\hline foreign & 52 & .1181465 & .2174435 & 0 & .9054 \\
\hline independ & 52 & .3157061 & .2213089 & 0 & .9090909 \\
\hline tq & 47 & 1.737945 & 1.446024 & .0575709 & 7.89641 \\
\hline prof & 52 & .07451 & .1023031 & -.2273551 & .3624652 \\
\hline roe & 52 & -.0790891 & .7102157 & -3.915797 & .4861394 \\
\hline size & 52 & 7.938083 & 1.485286 & 4.587875 & 12.53699 \\
\hline size1 & 52 & 7.514088 & 1.310763 & 4.569355 & 11.45724 \\
\hline gcapex & 49 & .0724743 & .0614674 & 0 & .3086598 \\
\hline beta & 50 & .747502 & .2067084 & .3578 & 1.153 \\
\hline Variable & Obs & Mean & Std. Dev. & Min & Max \\
\hline \multicolumn{6}{|c|}{2010 year } \\
\hline gsales_t & 52 & .1586663 & .1450098 & -.1116582 & .7249448 \\
\hline gsales_p & 48 & .3588154 & .2274097 & .0018324 & 1.246115 \\
\hline gsales_m & 51 & -.025379 & .1750847 & -.3759351 & .406795 \\
\hline tdr & 51 & .4746939 & .5889478 & 0 & 4.059803 \\
\hline mtdr & 50 & .3089981 & .2424924 & 0 & .8984383 \\
\hline tangibility & 51 & .4919612 & .2387062 & .0411096 & .8762923 \\
\hline oc3 & 52 & .6741078 & .2117503 & 0 & 1 \\
\hline foreign & 52 & .1256173 & .2234532 & 0 & .9349 \\
\hline independ & 50 & .3523082 & .2125826 & 0 & .8181818 \\
\hline tq & 47 & 2.503412 & 2.125462 & .0818347 & 9.708097 \\
\hline prof & 52 & .1068187 & .0844289 & -.0588106 & .4709601 \\
\hline roe & 51 & .1449929 & .1760992 & -.2038175 & .9350551 \\
\hline size & 51 & 8.028562 & 1.489016 & 4.868293 & 12.61975 \\
\hline size1 & 51 & 7.703332 & 1.398352 & 4.736198 & 11.68268 \\
\hline gcapex & 50 & .0745883 & .058329 & 0 & .3196178 \\
\hline beta & 48 & .7591354 & .1636483 & .3923 & 1.1459 \\
\hline
\end{tabular}




\section{Appendix 2. Correlation matrix of variables}

\begin{tabular}{|c|c|c|c|c|c|c|c|c|c|c|c|}
\hline beta & $\mathrm{tq}$ & gsales_t & gcapex & $\mathrm{tdr}$ & oc3 & foreign & Ind & prof & size & Tang & beta \\
\hline tq & 1.0000 & & & & & & & & & & \\
\hline gsales_t & 0.1515 & 1.0000 & & & & & & & & & \\
\hline gcapex & 0.0952 & 0.2202 & 1.0000 & & & & & & & & \\
\hline $\operatorname{tdr}$ & 0.0212 & -0.2073 & 0.0326 & 1.0000 & & & & & & & \\
\hline oc3 & -0.1030 & -0.0087 & -0.1142 & -0.1253 & 1.0000 & & & & & & \\
\hline foreign & 0.1841 & 0.0574 & -0.0991 & -0.2640 & 0.0888 & 1.0000 & & & & & \\
\hline Ind & 0.0825 & -0.0347 & -0.0211 & 0.0983 & -0.0306 & 0.0043 & 1.0000 & & & & \\
\hline prof & 0.0350 & 0.0805 & -0.0074 & -0.3523 & 0.0875 & 0.2608 & 0.0356 & 1.0000 & & & \\
\hline size & -0.1671 & 0.0538 & 0.0369 & -0.2996 & 0.1932 & 0.0562 & 0.1607 & 0.1595 & 1.0000 & & \\
\hline Tang & -0.0889 & 0.0517 & 0.3715 & -0.2850 & 0.0683 & 0.0583 & -0.0398 & 0.0603 & 0.2897 & 1.0000 & \\
\hline beta & -0.1869 & -0.0959 & -0.0561 & -0.1023 & 0.0856 & -0.0087 & -0.0670 & 0.1218 & 0.3285 & 0.0583 & 1.0000 \\
\hline
\end{tabular}




\section{Appendix 3. Descriptive statistics of clusters across time periods}

\begin{tabular}{|c|c|c|c|c|c|c|c|c|c|c|c|c|c|c|c|}
\hline \multicolumn{16}{|c|}{ Precrisis cluster characteristics } \\
\hline cluster & Variable & tq & prof & roe & beta & mtdr & tdr & oc3 & Ind & foreign & manag & gcapex & gsales_m & gsales_p & gsales_t \\
\hline \multirow[b]{3}{*}{1} & Number & 37 & 42 & 40 & 33 & 39 & 43 & 43 & 43 & 43 & 36 & 43 & 31 & 42 & 43 \\
\hline & Mean & 2,1844 & 0,1257 & 0,1598 & 0,7810 & 0,2245 & 0,2808 & 0,6890 & 0,3017 & 0,0146 & 0,1548 & 0,0911 & 0,4245 & 0,3519 & 0,1577 \\
\hline & St.dev. & 1,6364 & 0,1054 & 0,1050 & 0,3473 & 0,2330 & 0,1829 & 0,2210 & 0,1173 & 0,0402 & 0,3408 & 0,0473 & 0,4370 & 0,3059 & 0,1854 \\
\hline \multirow[b]{3}{*}{2} & Number & 32 & 32 & 30 & 27 & 32 & 32 & 32 & 32 & 32 & 30 & 29 & 29 & 31 & 32 \\
\hline & Mean & 2,6302 & 0,1544 & 0,1870 & 0,6856 & 0,2223 & 0,2953 & 0,6835 & 0,3715 & 0,0361 & 0,1620 & 0,0783 & 0,4026 & 0,3791 & 0,1567 \\
\hline & St.dev. & 2,1318 & 0,0842 & 0,1137 & 0,3314 & 0,2171 & 0,1798 & 0,2016 & 0,1456 & 0,0839 & 0,2761 & 0,0482 & 0,2340 & 0,1981 & 0,0952 \\
\hline \multirow[b]{3}{*}{3} & Number & 31 & 36 & 32 & 32 & 32 & 36 & 36 & 36 & 36 & 33 & 33 & 30 & 32 & 36 \\
\hline & Mean & 2,9051 & 0,1388 & 0,2074 & 0,7684 & 0,3093 & 0,4330 & 0,7636 & 0,2847 & 0,1314 & 0,1974 & 0,1183 & 0,5552 & 0,3453 & 0,1459 \\
\hline & St.dev. & 2,1572 & 0,1276 & 0,1082 & 0,3942 & \begin{tabular}{|l|}
0,2993 \\
\end{tabular} & 0,1744 & 0,1520 & 0,1364 & 0,2499 & 0,2945 & 0,0836 & 1,1403 & 0,1792 & 0,1232 \\
\hline \multicolumn{16}{|c|}{2008 cluster characteristics } \\
\hline luster & ariable & tq & prof & roe & beta & mtdr & tdr & oc3 & Ind & foreign & manag & gcapex & gsales_m & gsales_p & gsales_t $t$ \\
\hline \multirow[b]{3}{*}{1} & Number & 14 & 14 & 12 & 13 & 14 & 14 & 14 & 14 & 14 & 14 & 14 & 13 & 13 & 14 \\
\hline & Mean & 1,2291 & 0,0966 & 0,1693 & 0,5842 & 0,4292 & 0,3188 & 0,6887 & 0,3442 & 0,0959 & 0,0398 & 0,1282 & 0,2479 & 0,3698 & 0,1921 \\
\hline & St.dev. & 2,1959 & 0,1465 & 0,1097 & 0,2610 & 0,3035 & 0,2050 & 0,1774 & 0,1859 & 0,2031 & 0,1302 & 0,0693 & 0,0825 & 0,3066 & 0,1846 \\
\hline \multirow[b]{3}{*}{2} & Number & 15 & 15 & 10 & 15 & 15 & 15 & 15 & 15 & 15 & 13 & 14 & 14 & 14 & 15 \\
\hline & Mean & 0,7640 & 0,1360 & 0,1650 & 1,0868 & 0,5313 & 0,3984 & 0,7219 & 0,4185 & 0,0224 & 0,2523 & 0,1073 & 2964 & 2949 &, 1399 \\
\hline & St.dev. & 0,7645 & 0,0903 & 0,1044 & 0,4664 & 0,2663 & 0,1770 & 0,1014 & 0,1980 & 0,0537 & 0,3589 & 0,0430 & 2027 &, 1620 & 0,0985 \\
\hline \multirow[b]{3}{*}{3} & Number & 17 & 17 & 11 & 17 & 17 & 17 & 17 & 17 & 17 & 15 & 17 & 16 & 15 & 17 \\
\hline & Mean & 1,3586 & 0,1236 & 0,2120 & 0,6324 & 0,5515 & 0,5073 & 0,7323 & 0,3981 & 0,1056 & 0,1591 & 0,1369 & 3325 & 3821 & 0,1470 \\
\hline & dev. & 1,1826 & | 0,0943 & 0,1328 & 0,3597 & 0,2707 & 0,2275 & 0,1453 & 0,1956 & 0,2233 & 0,2628 & 0,1432 & 0,1933 & 0,1879 & 0,1268 \\
\hline \multicolumn{16}{|c|}{2009 cluster characteristics } \\
\hline luster & Variable & tq & prof & roe & beta & mtdr & tdr & oc3 & Ind & foreign & manag & gcapex & gsales_m & gsales_p & gsales_t \\
\hline \multirow[b]{3}{*}{1} & Number & 16 & 17 & 13 & 16 & 17 & 17 & 17 & 17 & 17 & 16 & 17 & 17 & 16 & 17 \\
\hline & Mean & 1,4754 & 0,0862 & 0,1138 & 0,7834 & 0,2938 & 0,3185 & 0,6616 & 0,3390 & 0,2013 & 0,0560 & \begin{tabular}{|l|}
0,1038 \\
\end{tabular} & 0,0256 & 0,3470 & 0,1931 \\
\hline & St.dev. & 1,0047 & 0,0952 & 0,0799 & 0,1841 & 0,2198 & 0,2126 & 0,1486 & 0,2399 & 0,2832 & 0,2052 & 0,0796 & 0,1719 & 0,2830 & 0,1711 \\
\hline & Number & 12 & 12 & 8 & 12 & 12 & 12 & 12 & 12 & 12 & 10 & 10 & 12 & 11 & 12 \\
\hline & Mean & 1,8624 & 0,0616 & 0,1540 & 0,7707 & 0,3662 & 0,3988 & 0,7439 & 0,3669 & 0,0350 & 0,1929 & 0,0709 & 0,0039 & 0,2514 & 0,1501 \\
\hline & St.dev. & 1,2064 & 0,0733 & 0,1398 & 0,1979 & 0,2927 & 0,2517 & 0,1642 & 0,2239 & 0,0730 & ,3042 & 0,0410 & 2120 & 1633 & 0,0828 \\
\hline & Number & 14 & 16 & 11 & 16 & 15 & 16 & 16 & 16 & 16 & 14 & 15 & 16 & 14 & 16 \\
\hline & Mean & 2,0438 & 0,1035 & 0,1403 & 0,6869 & 0,4488 & 0,4741 & 0,7244 & 0,3036 & 0,1125 & 0,1322 & 0,0530 & $-0,0158$ & 0,4053 & 0,1407 \\
\hline & dev. & 2,1407 & \begin{tabular}{|l|}
0,0802 \\
\end{tabular} & 0,0831 & 0,2241 & 0,2863 & 0,2552 & 0,1605 & 0,2266 & 0,2256 & 0,2312 & \begin{tabular}{|l|}
0,0477 \\
\end{tabular} & 0,1422 &, 1708 & 0,1301 \\
\hline \multicolumn{16}{|c|}{2010 cluster characteristics } \\
\hline cluster & riable & tq & prof & roe & beta & mtdr & tdr & oc3 & Ind & foreign & manag & gcapex & gsales_m & gsales_p & gsales_t \\
\hline \multirow[b]{3}{*}{1} & Number & 14 & 15 & 13 & 14 & 15 & 15 & 15 & 15 & 15 & 13 & 15 & 15 & 14 & 15 \\
\hline & Mean & 2,0109 & 0,1144 & 0,1441 & 0,7629 & 0,2149 & 0,2830 & 0,6959 & 0,3539 & 0,2388 & 0,0675 & 0,0862 & 0,0159 & 0,3704 & 0,2066 \\
\hline & dev. & 1,4936 & 0,0700 & 0,0773 & 0,1927 & 0,1920 & 0,2026 & 0,1488 & 0,1966 & 0,2820 & 0,2278 & 0,0618 &, 1546 & 0,2952 & 0,1783 \\
\hline & Number & 13 & 13 & 11 & 13 & 13 & 13 & 13 & 13 & 13 & 11 & 12 & 13 & 12 & 13 \\
\hline & Mean & 2,1536 & 0,0892 & 0,1650 & 0,7680 & 0,3369 & 0,4031 & 0,6186 & 0,3932 & 0,0241 & 0,1975 & 0,0760 & $-0,0214$ & 0,2949 & 0,1515 \\
\hline & St.dev. & 1,3781 & 0,0597 & 0,0910 & 0,1659 & 0,2609 & 0,2360 & 0,2497 & 0,2157 & 0,0438 & 0,2762 & 0,0366 & 0,1770 & 0,1744 & 0,0833 \\
\hline \multirow[b]{3}{*}{3} & Number & 14 & 15 & 14 & 14 & 14 & 15 & 15 & 15 & 15 & 12 & 15 & 15 & 13 & 15 \\
\hline & Mean & 3,6114 & 0,1082 & 0,2070 & 0,7187 & 0,3232 & 0,4327 & 0,7361 & 0,3512 & 0,1395 & 0,1536 & \begin{tabular}{|l|}
0,0663 \\
\end{tabular} & $-0,0531$ & 0,3770 & 0,1388 \\
\hline & St.dev. & 3,0823 & 0,0711 & 0,2387 & 0,0913 & $\mid 0,2822$ & 0,2299 & 0,1720 & 0,2536 & 0,2572 & 0,2463 & $\mid 0,0784$ & 0,1868 & 0,1860 & 0,1324 \\
\hline
\end{tabular}

